\title{
IMPLEMENTASI PEMBIAYAAN DENGAN AKAD MURABAHAH DI KOPERASI SEMBADA GUNA SYARIAH TAKERAN
}

\author{
Rini Wulandari \& Moch Tholhah \\ Email: rini.dari.dr@gmail.com
}

\begin{abstract}
Abstrak
Koperasi Sembada Guna Syariah (KSGS) Takeran menawarkan pembiayaan dengan akad murabahah. Namun dalam prakteknya tidak membelikan barang yang dibutuhkan namun memberi modal. Rumusan masalah dalam penelitian ini yaitu: (1) Bagaimana pelaksanan pembiayaan dengan akad murabahah di Koperasi Sembada Guna Syariah Takeran? (2) Bagaimana tinjauan hukum Islam terhadap pelaksanaan pembiayaan dengan akad murabahah di Koperasi Sembada Guna Syariah Takeran?

Pendekatan yang digunakan pada penelitian ini adalah pendekatan yuridis empiris. Melalui pendekatan ini akan diketahui pelaksanaan pembiayaan dengan akad murabahah di Koperasi Sembada Guna Syariah (KSGS) Takeran.

Hasil penelitian menemukan bahwa: (1) Praktek pelaksanaan pembiayaan murabahah di Koperasi Sembada Guna Syariah dilaksanakan dengan memberikan biaya secara tunai, bukan dengan membelikan barang. (2) Akad pembiayaan murabahah yang telah dipraktekkan oleh Koperasi Sembada Guna Takeran Magetan bila ditinjau dari konsep fiqh ternyata sudah sah dan sesuai, hal ini dapat dilihat dari akad pembiayaan yang dipraktekkan sudah sesuai dengan ketentuan-ketentuan syara', dan dengan adanya kesepakatan antara kedua belah pihak yaitu antara koperasi dengan nasabah.

Saran yang diajukan pada penelitian ini adalah (1) Perlu ditambah produk pembiayaan dengan prinsip syariah agar mampu memberikan kemudahan bagi kaum muslim. (2) Perlu penerapan sistem pembiayaan murabahah dengan sebenarnya agar tercapai visi misi yang telah dicantumkan. (3) Perlu bantuan dan pengawasan yang lebih intensif agar pembiayaan dengan akad murabahah dapat saling menguntungkan. (4) Sedapat mungkin plafond pembiayaan pada KSGS Takeran ditinggikan untuk lebih memberikan pemenuhan kebutuhan masyarakat.
\end{abstract}

\section{Kata Kunci : Pembiayaan, Murabahah, Koperasi.}

\section{PENDAHULUAN}

Bank adalah lembaga perantara keuangan atau biasa disebut financial intermediary. Artinya lembaga keuangan yang dalam aktivitasnya berkaitan dengan masalah uang yang merupakan alat pelancar terjadinya perdagangan yang utama. ${ }^{1}$ Menurut UndangUndang Perbankan No. 10 Tahun 1998 yang dimaksud dengan Bank adalah badan usaha

\footnotetext{
${ }^{1}$ Muhammad, Manajemen Dana Bank Syariah, (Yogyakarta:
} Ekonisia, 2004), 1. yang menghimpun dana dari masyarakat dalam bentuk simpanan dan menyalurkannya kepada masyarakat dalam bentuk kredit/pembiayaan atau bentuk lainnya dalam rangka meningkatkan taraf hidup rakyat banyak. ${ }^{2}$ Menurut UU Nomor 21 tahun 2008 tentang perbankan syariah menyatakan bahwa perbankan syariah adalah segala sesuatu yang menyangkut tentang bank syariah dan unit usaha syariah, mencakup kelembagaan,

\footnotetext{
${ }^{2}$ Ismail, Perbankan Syariah, (Jakarta: Kencana, 2011), 30.
} 
kegiatan usaha, serta cara dan proses dalam melaksanakan kegiatannya. ${ }^{3}$

Bank syariah adalah bank yang tidak beroperasi dengan tidak mengandalkan bunga. Bank islam atau biasa disebut dengan bank tanpa bunga adalah lembaga keuangan/perbankan yang operasional dan produknya dikembangkan berlandaskan pada Al-Qur'an dan Hadist Nabi SAW. Allah telah menurunkan larangan memakan riba secara berharap untuk mengurangi kesengsaraan masyarakat, terdapat pada QS. Al-Baqarah: $275^{4}$

Sedangkan yang dimaksud lembaga keuangan koperasi, menurut Undang-Undang No. 12 tahun 1967 tentang pokok-pokok perkoperasian, koperasi Indonesia adalah organisasi ekonomi rakyat berwatak sosial, beranggotakan orang-orang atau badan hukum koperasi yang merupakan tata susunan ekonomi sebagai usaha bersama berdasar atas asas kekeluargaan. $^{5}$

Menurut Undang-Undang No. 25 tahun 1992 tentang perkoperasian menyatakan bahwa, koperasi adalah badan usaha yang beranggotakan orang seorang atau badan hukum koperasi dengan melandaskan kegiatannya berdasarkan prinsip koperasi dan sekaligus sebagai gerakan ekonomi rakyat yang berdasar atas asas kekeluargaan. ${ }^{6}$

Bank syariah pertama kali muncul di Indonesia, berawal dari lahirnya Bank Muamalat Indonesia (BMI) sebagai sentral perekonomian yang bernuansa Islam, maka bermunculan lembaga-lembaga keuangan yang lain. Yaitu ditandai dengan tingginya semangat bank konvensional untuk mendirikan lembaga

\footnotetext{
${ }^{3}$ Ibid..... 33.

${ }^{4}$ Muhammad, Manajemen Bank Syari'ah (Yogyakarta: UPP AMP YKPN, 2002), 36.

${ }^{5}$ Lihat Pasal 3 Undang-Undang No. 12 tahun 1967 tentang Pokok-Pokok Koperasi.

${ }^{6}$ Lihat pasal 1 ayat 1 Undang-Undang No. 25 tahun 1992 tentang Perkoperasian.
}

keuangan Islam yaitu bank syari'ah. ${ }^{7}$ Tetapi karena operasionalisasi bank syari'ah di Indonesia kurang menjangkau usaha masyarakat kecil dan menengah, maka muncul usaha untuk mendirikan lembaga keuangan mikro seperti BPR syari'ah, BMT maupun koperasi syariah yang bertujuan untuk mengatasi hambatan operasioanalisasi di daerah-daerah.

Tumbuh dan berkembangnya lembaga keuangan mikro syariah ternyata saat ini telah menjangkau pelosok desa. Terbukti di wilayah Desa Takeran Kabupaten Magetan, juga telah berdiri lembaga keuangan mikro syariah berupa koperasi syariah yang bernama Koperasi Sembada Guna Syariah.

Pelaksanaan akad dengan prinsip syariah yang banyak dilaksanakan oleh koperasi tersebut salah satunya adalah pelaksanaan akad murabahah. Akad murabahah yang dimaksud adalah Murabahah yang berasal dari kata ArRibhu yang berarti an-anmaa' yang berarti tumbuh dan berkembang, atau Murabahah bisa diartikan juga Al-Irbaah, karena salah satu dari dua orang bertransaksi memberi keuntungan kepada lainnya.Secara istilah akad jual beli atas barang tertentu, di mana penjual menyebutkan harga pembelian barang kepada pihak pembeli dengan mensyaratkan keuntungan yang diharapkan sesuai jumlah tertentu.Dalam akad Murabahah, penjual menjual barangnya dengan meminta kelebihan atas harga beli dengan harga jual. ${ }^{8}$

Alasan yang paling mendasar banyaknya akad murabahah lebih banyak dipergunakan adalah dalam murabahah ini risiko bagi bank syariah adalah kecil. Secara sederhana, murabahah berarti pembiayaan dengan akad jual beli dimana harga dan keuntungan

\footnotetext{
7 Ahamad Sumiyanto, Menuju Koperasi Modern (Panduan untuk Pemilik, Pengelola dan Pemerhati Baitul maal wat Tamwii dalam format Koperasi), Yogyakarta: Debeta, 2008, 23.

${ }^{8}$ Ismail, PerbankanSyariah, (Jakarta: Kencana, 2011), 138.
} 
disepakati antara penjual dan pembeli, dalam lembaga keuangan model ini diaplikasikan antara nasabah dengan bank, nasabah sebagai pembeli dan bank sebagai penjual, dengan harga dan keuntungan disepakati di awal. Nasabah memerlukan suatu barang, bank mengeluarkan dana untuk membeli barang tersebut, kemudian barang disepakati dibeli oleh nasabah. ${ }^{9}$

Akad murabahah adalah salah satu akad yang banyak dipergunakan di dalam pemberian layanan di Koperasi Sembada Guna Syariah Takeran. Namun dalam pelaksanaannya akad pembiayaan murabahah ini dicairkan dalam bentuk biaya maksimal 5 juta rupiah untuk berbagai keperluan.

Alasan inilah yang melatarbelakangi penulis melakukan penelitian mengenai: "Implementasi Pembiayaan dengan Akad Murabahah Di Koperasi Sembada Guna Syariah Takeran".

\section{PEMBAHASAN}

\section{Murabahah}

\section{Pengertian Murabahah}

Murabahah berasal dari kata Ar-Ribhu yang berarti an-anmaa' yang berarti tumbuh dan berkembang, atau Murabahah bisa diartikan juga Al-Irbaah, karena salah satu dari dua orang bertransaksi memberi keuntungan kepada lainnya. Secara istilah akad jual beli atas barang tertentu, di mana penjual menyebutkan harga pembelian barang kepada pihak pembeli dengan mensyaratkan keuntungan yang diharapkan sesuai jumlah tertentu. Dalam akad Murabahah, penjual menjual barangnya dengan meminta kelebihan atas harga beli dengan harga jual. ${ }^{1}$ Bank Islam mengambil murabahah untuk memberikan pembiayaan jangka pendek kepada kliennya untuk membeli barang walaupun kliennya tersebut mungkin tidak memiliki uang tunai

\footnotetext{
9 Muhammad Syarif Arbi, Lembaga: Perbankan, Keuangan dan Pembiayaan, (Yogyakarta: BPFE Anggota IKAPI, 2013), 233.
}

untuk membayar. Murabahah sebagaimana digunakan dalam perbankan islam, ditemukan terutama berdasarkan dua unsur. Harga membeli dan biaya yang terkait, dan kesepakatan berdasarkan mark-up (keuntungan). ${ }^{2}$

Murabahah didefinisikan oleh para fuqoha sebagai penjualan barang seharga biaya/harga pokok (cost) barang tersebut ditambah mark-up atau margin keuntungan yang disepakati. Menurut Fatwa DSN (Dewan Syariah Nasional) dijelaskan bahwa yang dimaksud dengan murabahah (DSN, 2003:311) adalah menjual suatu barang dengan menegaskan harga belinya dan pembeli membayarnya dengan harga yang lebih sebagai laba. ${ }^{10}$

Murabahah berdasarkan PSAK 102 (paragraf 5) adalah akad jual beli barang dengan harga jual sebesar biaya perolehan ditambah keuntungan yang disepakati dan penjual harus mengungkapkan biaya perolehan barang tersebut kepada pembeli. ${ }^{11}$ Dalam jual beli secara umum, mekanisme pembayaran secara tunai, dengan mekanisme murabahah, jual beli menjadi bersifat tangguh dalam pembayaran, serta penjual dapat mengambil keuntungan dari barang tersebutyang dibeli. ${ }^{12}$ Murabahah, seperti yang dipahami di sini, digunakan dalam setiap pembiayaan di mana ada barang yang bisa diidentifikasi untuk dijual. ${ }^{13}$ Dalam konteks fiqh, murabahah merupakan bagian bahasan dari jual beli (bay'i). Murabahah merupakan salah satu jenis jual beli bila dilihat dari segi penukaran. Dari

\footnotetext{
10 Wiroso, Jual Beli Murabahah (Yogyakarta: UII Press, 2005), 13-14.

11 Rizal Yaya, Aji Erlangga Martawireja, Ahim Abdurahim, Akuntansi Perbankan Syariah:

Teori dan Praktik Kotemporer, (Jakarta: Salemba Empat, 2014), 160.

12 Ahmad Dahlan, Bank Syariah, (Yogyakarta: Teras, 2012), 190.

13 Abdullah Saeed, Menyoal Bank Syariah, (Jakarta: Paramadina, 2004), 120.
} 
penukaran, menurut Wahbah al-Zuhayli, jual beli terbagi kepada lima macam:

a) Bay' al-musawamah, yakni jual beli dengan sembarang harga dengan tanpa mempertimbangkan harga awal atau harga belinya.

b) Bay' al-murabahah, yaitu jual beli dengan harga jual yang sama dengan harga awal ditambah dengan keuntungan.

c) Bay' al-tawliyah, yaitu jual beli dengan harga yang sama dengan harga awal dengan tanpa ada sedikitpun tambahan keuntungan.

Sebagaimana yang telah dikemukakan di atas bahwa murabahah adalah jual beli dengan harga dan keuntungan yang diketahui. Dalam konteks fiqh, ada beberapa syarat yang mesti dipenuhi dalam akad murabahah. Menurut Wahbah al-Zuhaili, dalam murabahah ditetapkan syarat-syarat sebagai berikut:

a) Mengetahui harga produk

Dalam jual beli murabahah disyaratkan agar mengetahui harga pokok atau harga asal, karena mengetahui harga merupakan syarat sah jual beli. Syarat mengetahui harga pokok atau harga asal ini juga diperuntukkan bagi jual beli at-tauliyah dan al-wadhiah

b) Mengetahui keuntungan

Hendaknya margin keuntungan juga diketahui oleh si pembeli, karena margin keuntungan tersebut termasuk bagian dari harga yang harus diserahkan oleh pihak pembeli kepada pihak penjual. Sedangkan mengetahui harga merupakan syarat sah jual beli.

Harga pokok merupakan sesuatu yang dapat diukur, dihitung dan ditimbang, baik pada waktu terjadi jual beli dengan penjual yang pertama atau setelahnya. Oleh karena itu, harga pokok ini biasanya ditentukan oleh nilai, seperti nilai mata uang. ${ }^{14}$

2. Landasan Murabahah

a. Landasan Hukum Murabahah

\footnotetext{
${ }^{14}$ Yadi Janwari, Lembaga Keuangan Syariah, (Bandung: PT Remaja Rosdakarya Offset, 2015), 16.
}

1) Pasal 1 ayat (13) Undang-Undang Nomor 10 Tahun 1998 tentang perbankan.

2) PBI No. 9/19/PBI/2007 jo. PBI No. 101/16/PBI/2008 tentang Pelaksanaan Prinsip Syariah dalam Kegiatan Penghimpunan Dana dan Penyaluran Dana serta Pelayanan Jasa Bank Syariah.

3) Peraturan Bank Indonesia Nomor 10/17/PBI/2008 tentang Produk Bank Syariah dan Unit Usaha Syariah.

4) Ketentuan pembiayaan murabahah dalampraktik perbankan syariah di Indonesia dijelaskan dalam Fatwa Dewan Syariah Nasional No. 04/DSN-MUI/IV/2000 tentang Murabahah.

5) Pasal 19 Undang-Undang Nomor 21 Tahun 2008 tentang Perbankan Syariah yang mengatur mengenai kegiatan usaha Bank Umum Syariah yang salah satunya adalah pembiayaan murabahah. ${ }^{15}$

b. Landasan Syariah Murabahah

1) a) QS. Al-Baqarah(2) ayat 275 ।

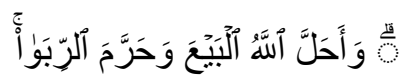

$$
\begin{aligned}
& \text { Artinya:"Allah menghalalkan jualbeli } \\
& \text { dan mengharamkan riba" }
\end{aligned}
$$

2) HR. Ibnu Majah

Dari Shuaib Ar Rumi R.A. bahwa Rasulullah SAW bersabda, "Tiga hal yang di dalamnya terdapat keberkahan yaitu jual beli secara tangguh, muqaradhah (mudharabah) dan mencampur gandum dengan tepung untuk keperluan rumah."16

c. Ketentuan Fatwa tentang Murabahah

Ketentuan tentang Murabahah yang dikeluarkan oleh MUI adalah fatwa Nomor 4/DSN-MUI/IV/2000:

15 Bagya Agung Prabowo, Aspek Hukum Pembiayaan Murabahah pada Perbankan Syariah, (Yogyakarta: UII Press, 2012),. 29.

${ }^{16}$ Rizal Yaya, Aji Erlangga Martawireja, Ahim Abdurahim, Akuntansi Perbankan Syariah:

Teori dan Praktik Kotemporer, (Jakarta: Salemba Empat, 2014), 160. 
1) Ketentuan Umum Murabahah yang terdapat dalam bank syariah

a) Bank dan Nasabah harus melakukan akad murabahah yang bebas dari riba.

b) Barang yang diperjualbelikan tidak diharamkan oleh syariah Islam.

c) Bank membiayai sebagian atau seluruh harga pembelian barang yang telah disepakati kualifikasinya.

d) Bank membeli barang yang dipeerlukan nasabah dan atas nama bank sendiri, dan pembelian ini harus sah dan bebas dari riba.

e) Bank harus menyampaikan semua hal yang berkaitan dengan pembelian, misalnya jika pembelian dilakukan secara hutang.

f) Bank kemudian menjual barang tersebut kepada nasabah (pemesan) dengan harga jual senilai harga beli ditambah keuntungan. Dalam kaitan ini bank harus memberitahu secara jujur harga pokok barang kepada nasabah berikut biaya yang diperlukan.

g) Nasabah membayar harga barang yang telah disepakati tersebut jangka waktu tertentu yang telah disepakati.

h) Untuk mencegah terjadinya penyalahgunaan atau kerusakan akad tersebut, pihak dapat mengadakan perjanjian khusus dengan nasabah.

i) Jika bank hendak mewakilkan kepada nasabah untuk membeli barang dari pihak ketiga, akad jual beli murabahah harus dilakukan setelah barang, secara prinsip menjadi milik bank. ${ }^{17}$

2) Ketentuan Murabahah kepada nasabah yang juga tertuang dalam fatwa dimaksud adalah sebagai berikut:

17 Muhammad, Model-Model Akad Pembiayaan di Bank Syari'ah, (Yogyakarta: UII Press,

2009),. 62-63. a. Nasabah mengajukan permohonan dan perjanjian pembelian barang atau asset kepada bank.

b. Jika bank menerima permohonan tersebut, ia harus membeli terlebih dahulu asset yang dipesannya secara sah dengan pedagang.

c. Bank kemudian menawarkan aset tersebut kepada nasabah dan nasabah harus menemani membelinya sesuai dengan perjania yang telah disepakatinya, kearena secara hukum perjanjian tersebut mengikat, kenudian kedua belah pihak harus membuat kontrak jual beli.

d. Dalam jual beli bank diperbolehkan meminta nasabah untuk membayar uang muka saat menandatangani kesepakatan awal pemesanan.

e. Jika nasabah kemudian menolak membeli barang tersebut, biaya riil bank harus dibayari dari uang muka tersebut. ${ }^{18}$

f. Jika nilai uang muka kurang dari kerugian yang harus ditanggung oleh bank, bank harus dapat meminta kembali sisa kerugiannya kepada nasabah.

g. Jika uang muka memakai kontrak urbun sebagai alternatif dari uang muka, maka jika nasabah memutuskan untuk membeli barang tersebut, ia tinggal memebayar sisa harga.

\section{Hutang dalam Murabahah}

Secara prinsip penyelesaian hutang si pemesan dalam transaksi murabahah tidak ada kaitannya dengan transaksi lain yang dilakukan si pemesan kepada pihak ketiga atas barang pesanan tersebut. Apakah si pemesan menjual kembali barang tersebut dengan keuntungan atau kerugian, ia tetap berkewajiban menyelesaiakan hutangnya kepada si pembeli.Jika pemesan menjual barang tersebut sebelummasa angsurannya berakhir, ia tidak wajib segera melunasi seluruh angsurannya.

${ }^{18}$ Ibid..., 63. 
Seandainya penjualan aset tersebut merugi, contohnya kalau nasabah adalah pedagang juga, pemesan tetap harus menyelesaikan pinjamnanya sesuaai kesepakatan awal. Hal ini karena transaksi penjualan kepada pihak ketiga yang dilakukan nasabah merupakan akad yang benar-benar terpisah dari akad murabahah pertama dengan bank. ${ }^{19}$

4. Penundaan pembayaran dalam Murabahah

a. Nasabah yang memiliki kemampuan tidak dibenarkan menunda penyelesaian hutangnya.

b. Jika nasabah menunda-nunda pembayaran dengan sengaja, atau jika salah satu pihak menunaikan kewajibannya, maka penyelesaiannya dilakukan melalui Badan Arbritase Syariah setelah tidak tercapai kesepakatan melalui musyawarah. ${ }^{20}$ Bangkrut dalam murabahah: jika nasabah telah dinyatakan pailit dan gagal menyelesaikan hutangnya, bank harus menunda tagihan hutang sampai ia menjadi sanggup kembali, atau berdasarkan kesepakatan. $^{21}$

Bangkrut dalam Murabahah

Jika pemesan yang berhutang dianggap pailit dan gagal menyelesaikan hutangnya karena benar-benar tidak mampu secara ekonomi dan bukan karena lalai sedangkan ia mampu, kreditor harus menunda tagihan utang sampai menjadi sanggup kembali. Dalam hal ini, Allah SWT telah berfirman,

19 Muhammad Syafiei Antonio, Bank Syariah dari Teori ke Praktik (Jakarta : Gema Insani Press,

2001), h. 105.

20 Muhammad, Model-Model Akad Pembiayaan di Bank Syari'ah, (Yogyakarta: UII Press, 2009), 64

21 Khotibul Umam, Legislasi Fikih Ekonomi dan Penerapannya dalam Produk Perbankan Syariah Di Indonesia, (Yogyakarta: BPFE Anggota IKAPI, 2011), 101.
Artinya: "dan jika (orang berhutang itu) dalam kesukaran, berilah tangguh sampai dia berkelapangan......."(al-Baqarah: 280). ${ }^{22}$

5. Rukun dan Syarat Murabahah

Rukun jual beli menurut mahzab Hanafi adalah ijab dan qabul yang menunjukan adanya penukaran atau kegiatan saling memberi yang menempati kedudukan ijab qabul tersebut. Rukun ini dengan ungkapan lain merupakan pekerjaan yang menunjukan keridhaan dengan adanya penukaran dua harta milik, baik berupa perkataan maupun perbuatan.

Menurut Jumhur Ulama ada 4 rukun akad jual beli, yaitu:

a. Orang yang menjual

b. Orang yang membeli

c. Sighat (ijab dan qabul)

d. Barang atau sesuatu yang diakadkan

Rukun jual beli menurut Jumhur Ulama, selain mahzab Hanafi ada 3, yaitu:

1. Orang yang berakad (penjual dan pembeli)

2. Yang diakadkan (harga dan barang yang dihargai)

3. Sighat (ijab dan qabul) ${ }^{23}$

Adapun syarat-syarat dalam murabahah antara lain adalah sebagai berikut:

1.Penjual memberi tahu biaya modal kepada nasabah.

2. Kontrak pertama harus sah sesuai dengan rukun yang ditetapkan.

3. Kontrak harus bebas dari riba.

6. Jenis Pembiayaan Murabahah

Menurut Muhammad dalam bukunya "Model-Model Akad Pembiayaaan Di Bank Syariah (Panduan Teknis Pembuatan Akad/Perjanjian Pembiayaan Di Bank Syariah)", murabahah dibedakan menjadi dua

\footnotetext{
22 MuhammadSyafiei Antonio, Bank SyariahdariTeorikePraktik(Jakarta :GemaInsani Press, 2001), 106.

23 Wiroso, Jual Beli Murabahah, (Yogyakarta: UII Press, 2005), 16.
} 
macam yaitu: murabahah berdasarkan pesanan dan murabahah tanpa pesanan.

a. Dalam murabahah berdasarkan pesanan, bank melakukan pembelian barang setelah ada pemesaanan dari nasabah.Murabahah berdasarkan pesanan dapat bersifat mengikat atau tanpa mengikat nasabah untuk membeli barang yang dipesannya. Pembayaran murabahah dapat dilakukan secara tuani atau cicilan. ${ }^{24}$

b. Murabahah tanpa pesanan, murabahah ini termasuk jenis murabahah yang bersifat tidak mengikat. Murabahah ini dilakukan tidak melihat ada yang pesan atau tidak sehingga penyedia barang dilakukan sendiri oleh penjual. ${ }^{25}$

7. Implementasi Murabahah di Lembaga

Keuangan Syariah

Murabahah sebagai bagian dari jual beli yang ada transparansi antara penjual dan pembeli dalam harga jual dan harga beli telah banyak diimplementasikan di lembaga keuangan syariah. Saat ini, bagaimanapun, murabahah lebih banyak digunakan di aspek pembiayaan, baik di lembaga keuangan bank maupun di lembaga keuangan bukan bank. ${ }^{26}$

\section{Pembiayaan}

Penelitian ini akan membahas tentang pembiayaan tanpa agunan. Untuk itu perlu dikemukakan pengertian tentang pembiayaan itu sendiri. Menurut Undang-undang Pokok Perbankan No. 10 tahun 1998, pengertian pembiayaan adalah penyediaan atau tagihan yang dipersamakan dengan itu berdasarkan persetujuan atau kesepakatan antara bank dengan pihak lain yang mewajibkan pihak yang dibiayai untuk mengembalikan uang atau

\footnotetext{
${ }^{24}$ Muhammad Syafiee i Antonio, Bank Syariah dari Teori ke Praktik (Jakarta : Gema Insani Press, 2001), 102-103.

25 Bagya Agung Prabowo, Aspek Hukum Pembiayaan Murabahah pada Perbankan Syariah, (Yogyakarta: UII Press, 2012), 60.

26 Yadi Janwari, Lembaga Keuangan Syariah, (Bandung: PT Remaja Rosdakarya Offset, 2015),. 19.
}

tagihan tersebut setelah jangka waktu tertentu dengan imbalan atau bagi hasil. ${ }^{27}$

Sementara itu Kasmir menjelaskan pengertian pembiayaan adalah penyediaan uang atau tagihan yang dapat dipersamakan dengan itu, berdasarkan persetujuan atau kesepakatan antara bank dengan pihak lain yang mewajibkan pihak yang dibiayai untuk mengembalikan uang atau tagihan tersebut setelah jangka waktu tertentu dengan imbalan atau bagi hasil. ${ }^{28}$ Membahas tentang pembiayaan, Syafi'i Antonio mengemukakan pendapatnya bahwa :

Dalam perbankan syari'ah sebenarnya penggunaan kata pinjam meminjam kurang tepat digunakan disebabkan dua hal : pertama, pinjaman merupakan salah satu metode hubungan finansial dalam Islam. Kedua, pinjam meminjam adalah akad komersial yang artinya bila seseorang meminjam sesuatu ia tidak boleh diisyaratkan untuk memberikan tambahan atas pokok pinjamannya, karena setiap pinjaman yang menghasilkan manfaat adalah riba, sedangkan para ulama' sepakat bahwa riba itu haram. Oleh karena itu dalam perbankan syari'ah, pinjaman tidak disebut kredit akan tetapi disebut pembiayaan. ${ }^{29}$

Sedangkan menurut Muhammad mengemukakan pendapatnya bahwa :

Pembiayaan secara luas berarti finansial atau pembelanjaan, yaitu pendanaan yang dikeluarkan untuk mendukung investasi yang telah direncanakan, baik dilakukan sendiri maupun dijalankan oleh orang lain. Sedangkan, dalam arti sempit pembiayaan dipakai untuk mendefinisikan pendanaan yang dilakukan oleh lembaga pembiayaan. Namun, dalam perbankan pembiayaan dikaitkan dengan bisnis di mana pembiayaan merupakan pendanaan baik aktif maupun pasif yang dilakukan oleh lembaga

\footnotetext{
${ }^{27}$ Undang-Undang Nomor 10 Tahun 1998 Tentang Perbankan

${ }^{28}$ Kasmir, Manajemen Perbankan, (Jakarta : PT Raja Grafindo Persada, 2001), 92

29 Syafi'i Antonio, Bank Syari'ah Dari Teori Ke Praktek, (Jakarta: Gema Insani, 2001), 170
} 
pembiayaan kepada nasabah dan bisnis merupakan aktivitas berupa jasa, perdagangan dan industri guna memaksimalkan nilai keuntungan. ${ }^{30}$

\section{A. Tujuan Pembiayaan}

Menurut Muhammad menjelaskan bahwa secara umum tujuan pembiayaan dibedakan menjadi dua kelompok, yaitu: tujuan pembiayaan untuk tingkat makro, dan tujuan pembiayaan untuk tingkat mikro. Secara makro pembiayaan bertujuan untuk :

a. Peningkatan ekonomi umat,

b. Tersedianya dana bagi peningkatan usaha,

c. Meningkatkan produktivitas,

d. Membuka lapangan kerja baru,

e. Terjadi distribusi pendapatan. ${ }^{31}$

Adapun tujuan pembiayaan secara mikro adalah dalam rangka untuk :

a. Upaya memaksimalkan laba,

b. Upaya memaksimalkan resiko, artinya: usaha yang dilakukan agar mampu menghasilkan laba maksimal, maka pengusaha harus mampu meminimalkan resiko yang mungkin timbul. Resiko kekurangan modal usaha dapat diperoleh melalui tindakan pembiayaan

c. Pendayagunaan sumber ekonomi, artinya sumber daya ekonomi dapat dikembangkan dengan melakukan mixing antara sumber daya alam dengan sumber daya manusia serta sumber daya modal. Jika sumber daya alam dan sumber daya manusianya ada akan tetapi sumber daya modalnya tidak ada, maka dipastikan diperlukan pembiayaan. Dengan demikian, pembiayaan pada dasarnya dapat meningkatkan daya guna sumbersumber daya ekonomi.

d. Penyaluran kelebihan dana, artinya dalam kehidupan masyarakat ini ada pihak yang

30 Muhammad, Lembaga-Lembaga Keuangan Umat Kontemporer, (Yogyakarta : UII Press, 2002), 260

${ }^{31}$ Ibid, 17 memiliki kelebihan sementara ada pihak yang kekurangan. ${ }^{32}$

\section{B. Pengertian Koperasi Jasa Keuangan Syariah}

Praktek usaha koperasi yang dikelola secara syariah telah tumbuh dan berkembang di masyarakat serta mengambil bagian penting dalam memberdayakan ekonomi masyarakat. Di masyarakat telah bermunculan BMT yang bernaung dalam kehidupan payung hukum koperasi. Hal inilah yang mendorong Menteri Negara Koperasi dan Usaha Kecil dan Menengah untuk menerbitkan Surat Keputusan Nomor 91/Kep/MKUKM/IX/2004 agar koperasi BMT (KSGS) harus juga tunduk dengan koperasi yaitu Undang-Undang Nomor 25 Tahun 1992 tentang perkoperasian.

Berdasarkan ketentuan yang disebut Koperasi Sembada Guna Syariah (KSGS) adalah koperasi yang kegiatan usahanya bergerak dibidang pembiayaan, investasi dan simpanan sesuai pola bagi hasil (syariah). ${ }^{33}$ Dengan demikian semua BMT yang ada di Indonesia dapat digolongkan dalam KSGS, mempunyai payung Hukum dan legal kegiatan operasionalnya asal saja memenuhi ketentuan perundang-undangan yang berlaku.

Pengertian BMT adalah balai usaha mandiri terpadu yang isinya berintikan konsep baitul mal wat tamwil, BMT sesuai namanya terdiri dari dua fungsi utama, baitul maal (bait = rumah maal= harta) dimaksudkan sebagai lembaga amil, zakat (LAZ) yaitu menerima titipan dana zakat, infaq dan shadaqah serta mengoptimalkan distribusinya sesuai dengan peraturan dan amanahnya, baitut tamwil (bait = rumah, attamwil = pengembangan harta) melakukan kegiatan pengembangan usahausaha produktif dan investasi dalam meningkatkan kualitas ekonomi pengusaha mikro dan kecil dengan antara lain mendorong

\footnotetext{
${ }^{32}$ Ibid, $17-18$

33 KPRI Kipas, KSGS dan UJKS, online pada http://edisi03.blogspot.co.id/2008/08/kjks-dan-ujks.html, diakses 09 Januari 2016 Jam 20:34 WIB
} 
kegiatan menabung dan menunjang pembiayaan kegiatan ekonominya. ${ }^{34}$

Dalam definisi operasionalnya KSGS adalah lembaga usaha ekonomi rakyat kecil yang beranggotakan orang atau badan hukum berdasarkan prinsip syari'ah dan prinsip koperasi. Dalam melaksanakan kegiatannya KSGS mempunyai asas dan landasan, visi, misi, fungsi dan prinsip-prinsip serta ciri khas yang dimiliki oleh KSGS sebagai lembaga keuangan syari'ah non bank yang mempunyai legalitas dan berbadan hukum.

\section{Tujuan Pengembangan Koperasi Syariah}

Sesuai dengan keputusan Menteri Negara Koperasi dan Usaha Kecil dan Menengah tentang petunjuk pelaksanaan kegiatan usaha Koperasi Jasa Keuangan Syariah Bab II Pasal 2, tujuan pengembangan Koperasi Jasa Keuangan Syariah/Unit Jasa Keuangan Syariah:

a. Meningkatkan program pemberdayaan ekonomi, khususnya di kalangan usaha mikro, kecil, menengah dan koperasi melalui sistem syariah

b. Mendorong kehidupan ekonomi syariah dalam kegiatan usaha mikro, kecil, dan menengah khususnya dan ekonomi Indonesia pada umumnya meningkatkan semangat dan peran serta anggota masyarakat dalam kegiatan Koperasi Jasa Keuangan Syariah.

\section{PEMBAHASAN}

\section{A. Sekilas Tentang Koperasi Sembada Guna Syariah Takeran Magetan}

Salah satu lembaga yang mempelopori berdirinya lembaga keuangan syariah di Kabupaten Magetan adalah Koperasi Koperasi Sembada Guna Syariah Takeran Magetan yang berkantor di Jalan Raya Takeran Magetan. Pada hari Sabtu tanggal 5 Juni 2010 diadakan pembukaan atau launching yang dihadiri oleh

\footnotetext{
34 Ahmad Rodoni dan Abdul hamid, Lembaga Keuangan
} Syari 'ah, (Jakarta: Zikrul Hakim, 2008), 60.
Dinas Koperasi Usaha Mikro Kecil Menengah dan Perindustrian, para tokoh masyarakat, pedagang, dan sebagainya. Hadir pula dalam kesempatan tersebut Calon Wakil Bupati Magetan, Ali Samsi yang memenangkan Pemilukada tanggal 12 Mei 2010 yang resmi akan dilantik tanggal 27 Juli. Beliau menyerahkan bantuan beasiswa secara simbolis kepada 80 orang siswa setingkat SD dan SLTP. ${ }^{35}$

Lembaga keuangan ini merupakan jawaban dari problematika selama ini yang dihadapi oleh umat Islam tentang masih minimnya lembaga keuangan yang dikelola secara syariah. Potensi umat Islam di Kabupaten Magetan sangat besar dalam sektor keuangan, perdagangan dan ekonomi sehingga dengan hadirnya Koperasi Koperasi Sembada Guna Syariah Takeran Magetan diharapkan potensi tersebut dapat didorong lebih maju lagi. Keberadaan Koperasi Koperasi Sembada Guna Syariah Takeran Magetan diharapkan mampu mengisi potensi tersebut dan memberikan sumbangan dalam pertumbuhan ekonomi masyarakat Kabupaten Magetan.

\section{Visi Misi dan Tujuan}

1) Visi :

Menjadi wadah yang diakui sebagai acuan dan diikuti sebagai teladan bagi usaha percepatan pengembangan dan penerapan sistim ekonomi dan etika bisnis islami di Indonesia, mandiri, bukan organisasi pemerintah, bukan organisasi politik dan/atau tidak merupakan bagiannya

2) Misi :

1. Menjadi wadah yang menghimpun seluruh sumber daya yang ada dan membangun sinergi antar pemangku kepentingan untuk mempercepat penerapan ekonomi syariah di berbagai bidang.

\footnotetext{
35 Arsip Koperasi Koperasi Sembada Guna Syariah Takeran Magetan, Company Profil, diambil tanggal 19 Oktober 2015
} 
2. Menjadi wadah dan wahana komunikasi, informasi, representasi, konsultasi, fasilitasi dan advokasi dalam rangka membentuk iklim ekonomi yang sesuai syariah.

3. Memelihara persatuan dan kesatuan dari para pemangku kepentingan ekonomi syariah sebagai regulator, ulama, pengusaha, akademisi, praktisi, tokoh masyarakat dan lain-lain.

4. Mendorong dan memotivasi anggota untuk meningkatkan kreatifitas, inovasi dan pembelajaran diri dalam mengembangkan berbagai usaha untuk mencapai maksud dan tujuan Masyarakat Ekonomi Syariah.

5. Menjadi wadah membangun kerjasama dan kemitraan dengan pemerintah, organisasi kemasyarakatan islam, organisasi ekonomi syariah lain, organisasi profesi, organisasi industri dan lain sebagainya dalam mengembangkan program percepatan pengembangan ekonomi syariah.

3) Tujuan

Meningkatkan kesejahteraan anggota dan pengelola dengan mengedepankan nilai-nilai syariah, menjunjung tinggi akhlakul karimah, serta mengutamakan kepuasan anggota. ${ }^{36}$

4) Kegiatan

1. Mewujudkan silaturahmi diantara pelaku-pelaku ekonomi, perorangan dan lembaga yang berkaitan dengan ekonomi syariah. Membangun sinergi dan kemitraan di antara perorangan dan lembaga-lembaga yang terlibat dalam kegiatan ekonomi syariah.

2. Mendorong pengembangan aktivitas ekonomi syariah sehingga menjadi pilihan utama bagi masyarakat dalam

${ }^{36}$ Arsip Koperasi Koperasi Sembada Guna Syariah Takeran Magetan, Company Profil, diambil tanggal 19 Oktober 2015 kegiatan usaha termasuk dalam hal investasi maupun pembiayaan.

3. Meningkatkan hubungan antar anggota dan otoritas yang terkait dengan kegitan ekonomi dan keuangan syariah. Meningkatkan kegiatan untuk membentuk sumber daya insani yang mempunyai akhlak, ilmu dan kemampuan untuk menjalankan dan mengembangkan kegiatan ekonomi syariah melalui penelitian, pengembangan dan pelatihan

4. Meningkatkan kesadaran dan keterlibatan anggota dan masyarakat melalui berbagai kegiatan edukasi dan sosialisasi, namun tidak terbatas pada seminar, talkshow, workshop, pameran, konferensi, pendampingan, pelatihan dan lain sebagainya.

5. Menginisiasi dan mengembangkan berbagai lembaga pendukung ekonomi dan keuangan syariah.

6. Mengembangkan hubungan kerja sama dan penyedia informasi serta dukungan bisnis kepada pelaku keuangan syariah di domestik dan luar negeri.

7. Mengembangkan standarisasi / akreditasi berbagai sektor industri dan sektor profesi yang sesuai syariah.

8. Mendorong dan memberikan dukungan kepada pemerintah, DPR dan organisasi regulator lainnya dalam menyediakan ketersediaan undangundang, peraturan pemerintah dan peraturan lainnya yang mendukung masyarakat menerapkan aktivitas ekonomi syariah.

\section{B. Tinjauan hukum Islam terhadap pelaksanaan pembiayaan dengan akad murabahah di Koperasi Sembada Guna Takeran Magetan}

Sebagai lembaga keuangan mikro syariah, Koperasi Sembada Guna Takeran Magetan dalam mengembangkan usahanya, 
berkewajiban mengetahui hal-hal yang dapat mengakibat suatu perjanjian menjadi sah atau tidak (fasid). Hal ini dimaksudkan agar muamalah berjalan sah dan segala tindakan jauh dari kerusakan yang terjadi dengan sebab suatu hal yang tidak dibenarkan syara'. Jual beli dalam hukum Islam diperbolehkan, setiap manusia berhak melakukannya dengan berdasarkan pada prinsip-prinsip yang telah diatur dalam syari'at Islam. Hukum murabahah telah disepakati oleh para ulama seluruhnya dengan landasan "Jual beli barang, dibenarkan syara". Adapun Firman Allah yang dijadikan dalil hukum sewa-menyewa diantaranya adalah

1. Al-Qur'an

Firman Allah Surat al-Baqarah:233 yang artinya:

"Dan jika kamu ingin anakmu disusukan oleh orang lain, maka tidak ada dosa bagimu apabila kamu memberikan pembayaran menurut yang patut. Bertaqwalah kepada Allah dan ketahuilah bahwa Allah Maha melihat apa yang kamu kerjakan”.

Surat Al-Kahfi ayat 77; yang artinya

"Maka keduanya berjalan; hingga tatkala keduanya sampai kepada penduduk suatu negeri, mereka minta dijamu kepada penduduk negeri itu, tetapi penduduk negeri itu tidak mau menjamu mereka, kemudian keduanya mendapatkan dalam negeri itu dinding rumah yang hamper roboh, Maka Khidhr menegakkan dinding itu. Musa berkata: "Jikalau kamu mau, niscaya kamu mengambil upah untuk itu".

2. Hadist

a. Imam Bukhori meriwayatkan dalam hadis dari Aisyah RA. Menyebutkan, yang artinya: "Rasulullah SAW dan Abu Bakar menyewa seseorang penunjuk jalan yang ahli dari bani Dail yang memeluk Agama kafir Quraisy, kedua beliau membayarnya dengan kendaraannya kepada orang tersebut, dan menjanjikannya digua Tsur sesudah tiga malam dengan kendaraan keduanya".

b. Hadits riwayat Imam Bukhori : yang artinya

"Tiga golongan yang aku memusuhinya besuk dihari kiamat, yaitu orang yang memberikan kepadaku kemudian menarik kembali, orang yang menjual orang yang merdeka kemudian makan harganya, dan orang yang memperkerjakan orang lain dan telah selesai pekerjaannya tetapi tidak memberikan upahnya".

Pakar-pakar keilmuan dan cendekiawan sepanjang sejarah di seluruh negeri telah sepakat akan legitimasi murabahah. ${ }^{37}$ Dari beberapa nash yang ada, kiranya dapat dipahami bahwa murabahah itu disyari'atkan dalam Islam, karena pada dasarnya manusia senantiasa terbentur pada keterbatasan dan kekurangan. Oleh karena itu, manusia antara yang satu dengan yang lain selalu terikat dan saling membutuhkan.

Murabahah merupakan salah satu aplikasi keterbatasan yang dibutuhkan manusia dalam kehidupan bermasyarakat. Oleh karena itu boleh dikatakan bahwa pada dasarnya murabahah itu adalah salah satu bentuk aktivitas antara dua pihak atau saling meringankan, serta termasuk salah satu bentuk tolong menolong yang diajarkan agama.

Murabahah merupakan salah satu jalan untuk memenuhi hajat manusia. Oleh sebab itu para ulama menilai bahwa murabahah itu merupkan suatu hal yang diperbolehkan. Begitu pula di Koperasi Sembada Guna Takeran Magetan, mekanisme dana yang digunakan

\footnotetext{
${ }^{37}$ Muhammad Syafi'I Antonio, Op.Cit, 35.
} 
untuk pembiayaan didapatkan dari menghimpun dana dari masyarakat, menyalurkan pembiayaan, menerima dana dan menyalurkan dana zakat, infaq, shodaqoh, melakukan kegiatan lain yang lazim dilakukan oleh Bank Pembiayaan Rakyat Syari'ah sepanjang disetujui oleh Dewan Pengawas Syariah.

Melihat prosedur pembiayaan murabahah yang dipraktekkan oleh Koperasi Sembada Guna Takeran Magetan diatas, maka bisa diketahui secara pasti apakah praktek pembiayaan sudah sesuai dengan fiqh ataukah belum. Hal ini bisa terlihat dari syarat sahnya Murabahah adalah sebagai berikut:

a. Kerelaan dua pihak yang melakukan akad

Saling merelakan antara pihak yang berakad ini berdasarkan firman Allah: surat An-Nisa : 29 sebagai berikut :

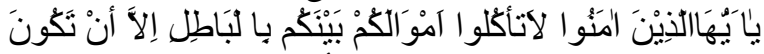

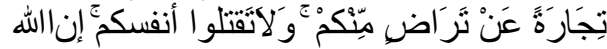

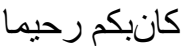

"Hai orang-orang yang beriman, janganlah kamu saling memakan harta sesamamu dengan jalan bathil, kecuali dengan jalan perniagaan yang berlaku dengan suka sama suka di antara kamu. Dan janganlah kamu membunuh dirimu, sesungguhnya Allah adalah Maha Penyayang kepadamu”.

b. Mengetahui manfaat dengan sempurna barang yang di akadkan, sehingga mencegah terjadinya perselisihan. ${ }^{38}$

c. Hendaklah barang yang menjadi objek transaksi dapat dimanfaatkan kegunaannya menurut kriteria, realita dan syara'

Maksud dari syarat ini adalah, kegunaan barang yang diperjualbelikan itu harus jelas dan dapat dimanfaatkan sesuai dengan kegunaannya menurut realita, kriteria dan syara'. ${ }^{39}$

Kemanfaatan yang dimaksud mubah dan tidak diharamkan adalah kemanfaatan yang

38 Syeikh Ali Ahmad Al-Jurjawi, Tarjamah Falsafah dan Hikmah Hukum Islam, (Semarang, Asy Syifa',1992), 397.

${ }^{39}$ Suhrawardi K. Lubis, Op.Cit, 146 tidak ada larangan dalam syara', kemanfaatan itu tidak sah apabila menyewakan tenaga (orang) dalam hal kemaksiatan, karena maksiat wajib ditinggalkan.

Sedangkan Rukun murabahah terdiri dari:

a. Sighat murabahah, yakni ijab dan qabul berupa pernyataan dari kedua belah pihak yang berakad (berkontrak), baik secara verbal atau dalam bentuk lain. Jual beli itu terjadi dan sah apabila ada ijab dan qabul, baik dalam bentuk perkataan atau dalam bentuk pernyataan lainnya yang menunjukkan adanya persetujuan antara kedua belah pihak dalam melakukan sewa-menyewa. ${ }^{40}$ Shighat ijab dan qabul adalah suatu ungkapan antara dua orang yang menyewakan suatu barang atau benda.

Ijab adalah permulaan penjelasan yang keluar dari seseorang yang berakad yang menggambarkan kemauannya dalam mengadakan akad, siapa saja yang memulai. Sedangkan qabul adalah jawaban (pihak) yang lain sesudah adanya ijab, dan untuk menerangkan persetujuannya. ${ }^{41}$

b. Aqid, yaitu pihak yang melakukan akad yakni pihak yang menyewa/pengguna jasa (musta'jir) dan pihak yang menyewakan/pemberi jasa (mu'ajjir).

c. Ma'qud alaih/Obyek akad murabahah, yakni :

1) Manfaat barang dan sewa, atau

2) Manfaat jasa dan upah ${ }^{42}$

Dengan melihat mekanisme tersebut, dapat disimpulkan bahwa pembiayaan murabahah yang dipraktekkan di Koperasi Sembada Guna Takeran Magetan ternyata telah

\footnotetext{
${ }^{40}$ Ibid

41 TM. Hasbi-Ash-Shiddieqy, Pengantar Fiqh Muamalah, (Jakarta, Bulan Bintang, 1984), 35

${ }^{42}$ Fatwa Dewan Syari'ah Nasional No. 09/DSN-MUI/IV/2000 tentang Pembiayaan Ijarah
} 
memenuhi ketentuan-ketentuan syara'. Menurut analisis penulis pembiayaan yang dipraktekkan oleh Koperasi Sembada Guna Takeran Magetan ini sudah sah karena syarat-syaratnya yang telah terpenuhi dengan benar. Namun pembiayaan pada Koperasi Sembada Guna Takeran Magetan kurang tepat dalam menerapkan akad murabahah karena dalam murabahah pemilik modal yang membelikan barang sedangkan dalam praktek di Koperasi Sembada Guna Syariah Takeran, modal diserahkan langsung kepada orang yang membutuhkan untuk dibelanjakan sendiri;

Murabahah yang dilakukan Koperasi Sembada Guna Takeran Magetan memang tidak sama persis dengan definisi murabahah yang dikenal dalam kitab fiqh. Dalam kitab fiqh dijelaskan bahwa murabahah Murabahah didefinisikan oleh para fuqoha sebagai penjualan barang seharga biaya/harga pokok (cost) barang tersebut ditambah mark-up atau margin keuntungan yang disepakati.

Praktek pembiayaan dengan akad murabahah yang dilaksanakan di Koperasi Sembada Guna Takeran Magetan bukanlah membelikan barang suatu barang untuk diambil manfaatnya ataupun mempekerjakan seseorang untuk diberikan upah. Praktek murabahah yang dilaksanakan oleh Koperasi Sembada Guna Takeran Magetan hanya menyalurkan dana talangan kepada nasabah yang memerlukan untuk biaya pendidikan, kesehatan dan biaya penanaman padi. Hal ini sesuai dengan hasil wawancara dengan Bapak Drs. Arif Wibowo selaku Manajer Koperasi Sembada Guna Takeran Magetan sebagai berikut :

"Dalam pembiayaan dengan akad murabahah yang digunakan untuk merenofasi rumah misalnya, dana yang diberikan oleh Koperasi Sembada Guna Takeran Magetan kepada nasabah itu bukan digunakan untuk membeli material, akan tetapi digunakan untuk membayar tukang. Sedangkan dalam pembiayaan pendidikan, pembiayaan murabahah yang diserahkan kepada nasabah itu diharapkan benar benar digunakan dalam pendidikan, bukan untuk hal hal lainnya". ${ }^{43}$

Walaupun tidak sama dengan fiqh, menurut analisis penulis, hal ini sah karena dilakukan demi kemaslahatan bersama. Selain itu, praktek pembiayaan yang diterapkan oleh Koperasi Sembada Guna Takeran Magetan telah sesuai dengan Syariah atas dasar fatwa DSN yang menyatakan bahwa obyek murabahah adalah manfaat dari penggunaan barang dan/atau jasa. Pembiayaan berdasarkan prinsip syari'ah berupa penyediaan uang atau tagihan yang dipersamakan dengan itu, berdasarkan persetujuan antara BPRS dengan nasabah, yang mewajibkan nasabah mengembalikan uang atau tagihan tersebut dalam jangka waktu tertentu, dengan imbalan atau ujrah. ${ }^{44}$

Secara teori dalam akad murabahah, baik pada saat bertransaksi ataupun tidak, penjual memang sudah memiliki persediaan barang untuk dijual belikan. Namun dari hasil penelitian dalam hal pembiayaan pembangunan rumah ini pihak bank belum memiliki persediaan barang yang akan dijualnya kepada nasabah. Tetapi salah satu ciri dari pembiayaan murabahah adalah diperbolehkannya bagi bank untuk memberikan kuasa kepada nasabah sebagai agen dari bank untuk membeli barang atas nama bank. Tidak terkecuali dengan nasabah KSGS Sembada Guna dalam mengajukan pembiayaan pembangunan rumah juga dimungkinkan untuk membeli sendiri bahan-bahan material untuk membangun rumah dengan kriteria dan keinginannya sendiri, namun pihak bank juga berhak melakukan penilaian terhadap supllier untuk menentukan apakah supllier tersebut layak atau tidak (sesuai kriteria yang sudah ditetapkan oleh bank). Hal

\footnotetext{
43 Hasil wawancara dengan Bp. Drs. Arif Wibowo selaku Manager Koperasi Sembada Guna Takeran Magetan, tanggal 19 Oktober 2015. 44 http:/www.pikiranrakyat.com/cetak/2006/062006/18/pundi.htm, diakses tanggal 18 Oktober 2015, Jam 20.16 WIB.
} 
ini terjadi karena berbagai alasan nasabah, misalnya nasabah ingin membangun rumah dengan harga murah dan jika ada diskonpun menjadi hak nasabah, tetapi sebagai lembaga pembiayaan, bank memperbolehkan nasabah membangun rumah dengan spesifikasi yang diinginkan dari supllier dengan mewakilkan atau memberi kuasa kepada nasabah dengan menggunakan akad wakalah.

\section{KESIMPULAN}

Berdasarkan hasil penelitian dan pembahasan yang telah dilakukan, maka dapat disimpulkan beberapa hal sebagai berikut :

\section{SARAN}

Berdasarkan kesimpulan di atas, maka dapat diajukan beberapa saran sebagai berikut :

1. Koperasi Sembada Guna Takeran Magetan harus tetap berkarya dalam membangun perekonomian untuk menopang kehidupan bermasyarakat dengan cara islam, terutama dalam mengeluarkan produk produk pembiayaan dengan prinsip syariah agar mampu memberikan kemudahan bagi kaum muslim.

2. Koperasi Sembada Guna Takeran Magetan diharapkan dapat menerapkan system pembiayaan dengan akad murabahah dengan sebenarnya agar tercapai visi misi yang telah

\section{DAFTAR PUSTAKA}

Muhammad, Manajemen Dana Bank Syariah, Yogyakarta: Ekonisia, 2004

, Menuju Koperasi Modern Panduan untuk

Pemilik, Pengelola dan Pemerhati Baitul

maal wat Tamwii dalam format Koperasi, Yogyakarta: Debeta, 2008

Syarif Arbi, Muhammad, Lembaga: Perbankan, Keuangan dan Pembiayaan, Yogyakarta: BPFE Anggota IKAPI, 2013

Wiroso, Jual Beli Murabahah, Yogyakarta: UII Press, 2005
1. Praktek pelaksanaan pembiayaan dengan akad murabahah di Koperasi Sembada Guna Syariah dilaksanakan dengan memberikan biaya secara tunai, bukan dengan membelikan barang.

2. Akad pembiayaan murabahah yang telah dipraktekkan oleh Koperasi Sembada Guna Takeran Magetan bila ditinjau dari konsep fiqh ternyata sudah sah dan sesuai, hal ini dapat dilihat dari akad pembiayaan yang dipraktekkan sudah sesuai dengan ketentuan-ketentuan syara', dan dengan adanya kesepakatan antara kedua belah pihak yaitu antara koperasi dengan nasabah.

dicantumkan. Selain itu, diharapkan Koperasi Sembada Guna Takeran Magetan tidak hanya berlebel syariah namun di dalamnya masih menggunakan sistem konvensional hanya untuk menarik nasabah.

3. Perlu bantuan dan pengawasan yang lebih intensif agar pembiayaan multijasa dengan akad murabahah dapat saling menguntungkan.

4. Sedapat mungkin diusahakan plafond pembiayaan pada Koperasi Sembada Guna Takeran Magetan ditinggikan untuk lebih memberikan pemenuhan kebutuhan masyarakat melalui kerja sama dengan BRI atau BNI, dan lain-lain.

Ismail, Perbankan Syariah, Jakarta: Kencana, 2011

Sumiyanto, Ahamad

Yaya, Rizal Aji Erlangga Martawireja, Ahim Abdurahim, Akuntansi Perbankan Syariah:Teori dan Praktik Kotemporer, Jakarta: Salemba Empat, 2014

Dahlan, Ahmad , Bank Syariah, Yogyakarta: Teras, 2012

Saeed, Abdullah, Menyoal Bank Syariah, (Jakarta: Paramadina, 2004), 120. 
Janwari , Yadi, Lembaga Keuangan Syariah, (Bandung: PT Remaja Rosdakarya Offset, 2015

Agung Prabowo, Bagya, Aspek Hukum Pembiayaan Murabahah pada Perbankan Syariah, Yogyakarta: UII Press, 2012

Syafieci Antonio, Muhammad, Bank Syariah dari Teori ke Praktik Jakarta : Gema Insani Press, 2001

Umam, Khotibul, Legislasi Fikih Ekonomi dan Penerapannya dalam Produk Perbankan Syariah Di Indonesia, Yogyakarta: BPFE Anggota IKAPI, 2011

Kasmir, Manajemen Perbankan, Jakarta : PT Raja Grafindo Persada, 2001

Ahmad Rodoni dan Abdul hamid, Lembaga Keuangan Syari'ah, Jakarta: Zikrul Hakim, 2008

Al-Jurjawi, Syeikh Ali Ahmad, Tarjamah Falsafah dan Hikmah Hukum Islam, Semarang, Asy Syifa',1992

Ash-Shiddieqy , TM. Hasbi-, Pengantar Fiqh Muamalah, Jakarta, Bulan Bintang, 1984 